\title{
Model of collective labour agreements in the Polish legal system
}

\section{Model układów zbiorowych pracy w systemie prawa polskiego \\ Professor Krzysztof W. Baran}

The Chair of Labour Law and Social Policy, Jagiellonian University krzysztof.baran@uj.edu.pl

ORCID: 0000-0001-5165-8265

\begin{abstract}
Summary The amendment of 5 July 2018 to the Act on Trade Unions provides in article 21(3) a statutory basis for the conclusion by the social partners of "non-employee" collective agreements. This eliminated a significant gap in the system of collective labour legislation. As from 1 January 2019 it will be possible to conclude collective agreements that are only for persons in gainful employment other than employees. Until now, they could have been beneficiaries of a collective agreement, provided that the personal scope of such agreement covered also non-employees. Thus the Constitutional freedom to bargain collectively and to conclude collective agreements has been fully implemented in the system of labour law. Article 59(2) of the Constitution of the Republic of Poland does not limit, in the personal sphere, the beneficiaries of collective agreements. In model terms, according to the personal criterion, de lege lata the Polish labour law provides three possible categories of collective agreements: employee collective agreements (Article 239 of the Polish Labour Code), non-employee collective agreements (Article 21(3) of the Act on Trade Unions), heterogeneous (hybrid) collective agreements.
\end{abstract}

Keywords: employee collective agreements, non-employee collective agreements, heterogeneous (hybrid) collective agreements.

Streszczenie Nowelizacja z 5 lipca 2018 r. ustawy o związkach zawodowych w art. 21 ust. 3 stworzyła podstawę ustawową dla zawierania przez partnerów społecznych „pozapracowniczych” („niepracowniczych”) układów zbiorowych pracy. Tym samym została wyeliminowana istotna luka w systemie ustawodawstwa zbiorowego. W ujęciu modelowym w systemie polskiego prawa pracy de lege lata możliwe jest zawieranie trzech podstawowych kategorii układów zbiorowych pracy: pracowniczych (art. 239 k.p.), pozapracowniczych (,niepracowniczych”, art. 21 ust. 3 ustawy o związkach zawodowych), heterogenicznych (hybrydowych).

Słowa kluczowe: pracownicze układy zbiorowe pracy, niepracownicze układy zbiorowe pracy, hetorogeniczne układy zbiorowe pracy

JEL: K31

Str. 6-8

\section{Bibliography}

Baran, K. W. (2018). O pojęciu pracodawcy w zbiorowym prawie pracy — uwagi de lege lata i de lege ferenda. Monitor Prawa Pracy, (3).

Baran, K. W. (2018a). O zakresie prawa koalicji w związkach zawodowych po nowelizacji prawa związkowego z 5 lipca 2018.

Praca i Zabezpieczenie Społeczne, (9).

Włodarczyk, M. (2017). In: System prawa pracy. Tom 1. Część ogólna. Warszawa.

Tomaszewska, M. (2014). In: System prawa pracy. Tom 5. Zbiorowe prawo pracy. Warszawa.

Żółyński, J. (2014). Ustawa o związach zawodowych. Komentarz. Warszawa. 